\title{
First record of the raccoon dog Nyctereutes procyonoides (Gray, 1834) in Luxembourg
}

\author{
Laurent Schley $^{1,2}$, Marianne Jacobs ${ }^{1,2,{ }^{*} \text {, Tiago De Sousa }}{ }^{1,2}$ \& \\ Jennifer Hatlauf ${ }^{2,3}$ \\ ${ }^{1}$ Administration de la nature et des forêts, 81 avenue de la Gare, \\ L-9233 Diekirch, Luxembourg. \\ ${ }^{2}$ Musée national d'histoire naturelle, 25 rue Münster, L-2160 Luxembourg, Luxembourg. \\ ${ }^{3}$ University of Natural Resources and Life Sciences (BOKU), Department of Integrative \\ Biology and Biodiversity Research, Institute of Wildlife Biology and Game Management, \\ Gregor-Mendel-Straße 33, A-1180 Vienna, Austria. \\ *Corresponding author: marianne.jacobs@anf.etat.lu
}

Keywords. Colonisation, geographic distribution, hunting, invasive alien species, management.

Schley L., Jacobs M., De Sousa T. \& Hatlauf J. (2021). First record of the raccoon dog Nyctereutes procyonoides (Gray, 1834) in Luxembourg. Belgian Journal of Zoology 151: 57-61. https://doi.org/10.26496/bjz.2021.85

Between 1929 and 1955, more than 9000 raccoon dogs Nyctereutes procyonoides (Gray, 1834) were introduced from their native range in southeast Siberia into the European parts of the former USSR (today: Belarus, Latvia, European part of Russia, and Ukraine) for hunting purposes [1][2]. From there, the species rapidly spread westwards, and by 1998, it was widely distributed in Finland, Lithuania, Latvia, Estonia, Poland, the Czech Republic, Slovakia, Bulgaria and Germany [1][2]. It was more sporadically present in Austria, Hungary, Romania and Serbia [1][3][4]. Since then, the raccoon dog has also been detected in Belgium [5], Croatia [6], France [7][8], Macedonia [9], the Netherlands [10], Switzerland [11] and Turkey [12].

There were indications regarding the presence of the raccoon dog in Luxembourg as early as 1997, but without confirmation [13]. On several occasions in the past, we launched appeals asking hunters to inform the Administration de la nature et des forêts (ANF) about any road-killed or hunted raccoon dogs [14][15]. However, none of the photos and carcasses that we could verify proved to be of raccoon dogs, but rather of raccoons Procyon lotor (Linnaeus, 1758) or European badgers Meles meles (Linnaeus, 1758) (Schley \& Jacobs, unpublished data), leaving Luxembourg without any confirmed raccoon dog records [16]. In the framework of Luxembourg's Natura-2000 monitoring of pine marten Martes martes (Linnaeus, 1758), Western polecat Mustela putorius Linnaeus, 1758 and wildcat Felis silvestris Schreber, 1777, $1691 \times 1 \mathrm{~km}$ squares were surveyed between 2011 and 2020, using camera traps. Of the 77749 photographs generated, 10889 were of European badgers, 
9514 of red foxes Vulpes vulpes (Linnaeus, 1758) and 5269 of raccoons, three other species with an opportunistic feeding behaviour, whereas not even one photograph showed a raccoon dog (Mestdagh, unpublished data), further pointing towards the absence of the latter in Luxembourg.

On 3 February 2021 at around 18.00, a hunter (D. Hipp) discovered an animal thought to be a raccoon dog hiding in a patch of high grass in an unmown meadow near the village of Livange in southern Luxembourg. She took photographs of the animal and sent those to the ANF for verification on 5 February 2021. We were able to confirm the species in the pictures (Fig. 1). The same day, we visited the meadow of the sighting with D. Hipp and were able to identify the exact spot where the photos had been taken (WGS84: $6.10777^{\circ} \mathrm{E}, 49.53823^{\circ} \mathrm{N}$ ) (Fig. 2). Therefore, to our best knowledge, this is the first confirmed record of the raccoon dog in Luxembourg.

In Luxembourg, the raccoon dog is listed in the appendix of the national hunting law and thus has the status of game species [17]; it can be hunted year-round (except for a six-week hunting-free period from 1 March to 15 April). Within the framework of the regulation on the prevention and management of the introduction and spread of invasive alien species of the European Union [18], the raccoon dog was included in the list of invasive alien species of Union concern in 2017 [19]. The reasons for inclusion were the possible negative impacts on native biodiversity (namely on ground-nesting birds and amphibians), the potential risk on human health, and its role in spreading diseases and parasites to other species, as the raccoon dog can be an important vector of rabies (RABV), sarcoptic mange, trichinellosis and Echinococcus multilocularis [2][10] [20][21].

The detection of the raccoon dog in Luxembourg raises conservation concerns, similar to those relating to the establishment and rapid spread of the raccoon [13][22]. Due to its cryptic behaviour, the raccoon dog is difficult to detect, especially during the early stages of colonisation [20]. A monitoring scheme should be put in place to determine whether the raccoon dog near Livange is likely a solitary individual or whether the species is established in the area. In the latter case, a management plan should be developed with all stakeholders to define further action, particularly given the high reproductive potential of the raccoon dog [21]. Considering the raccoon dog's expansion over the past decades, it seems likely that the species will eventually colonise large parts of Western Europe, including Luxembourg. Stopping this trend seems to be an impossible task, even with intensive hunting and significant means to monitor the spread, especially since there is evidence that the raccoon dog can compensate for high mortality with increased reproduction [23][24]. In view of this lost cause, the return of the wolf Canis lupus Linnaeus, 1758 to Luxembourg [25], if permanent, may contribute to the regulation of this invasive alien species. Indeed, this apex predator can be responsible for a high percentage (55-64\%) of raccoon dog mortality in the latter's native range [26], maybe less so in Europe (7\%) [27]. More rigorous protection measures, including various species-specific habitat improvements, should be implemented to protect vulnerable, known prey species to mitigate the raccoon dog's potential negative effects on native biodiversity.

\section{Acknowledgements}

We thank Danielle Hipp and Jeannot Havé for providing us with the information relating to the discovery of the raccoon dog and for allowing us to use the photograph, and Xavier Mestdagh (Luxemburg Institute of Science and Technology) for providing data from the Natura-2000 monitoring carried out under contract from the Ministry of the Environment, Climate and Sustainable Development. We are grateful to Isabelle Schön, Johan Michaux and two anonymous referees for valuable comments on the manuscript. 


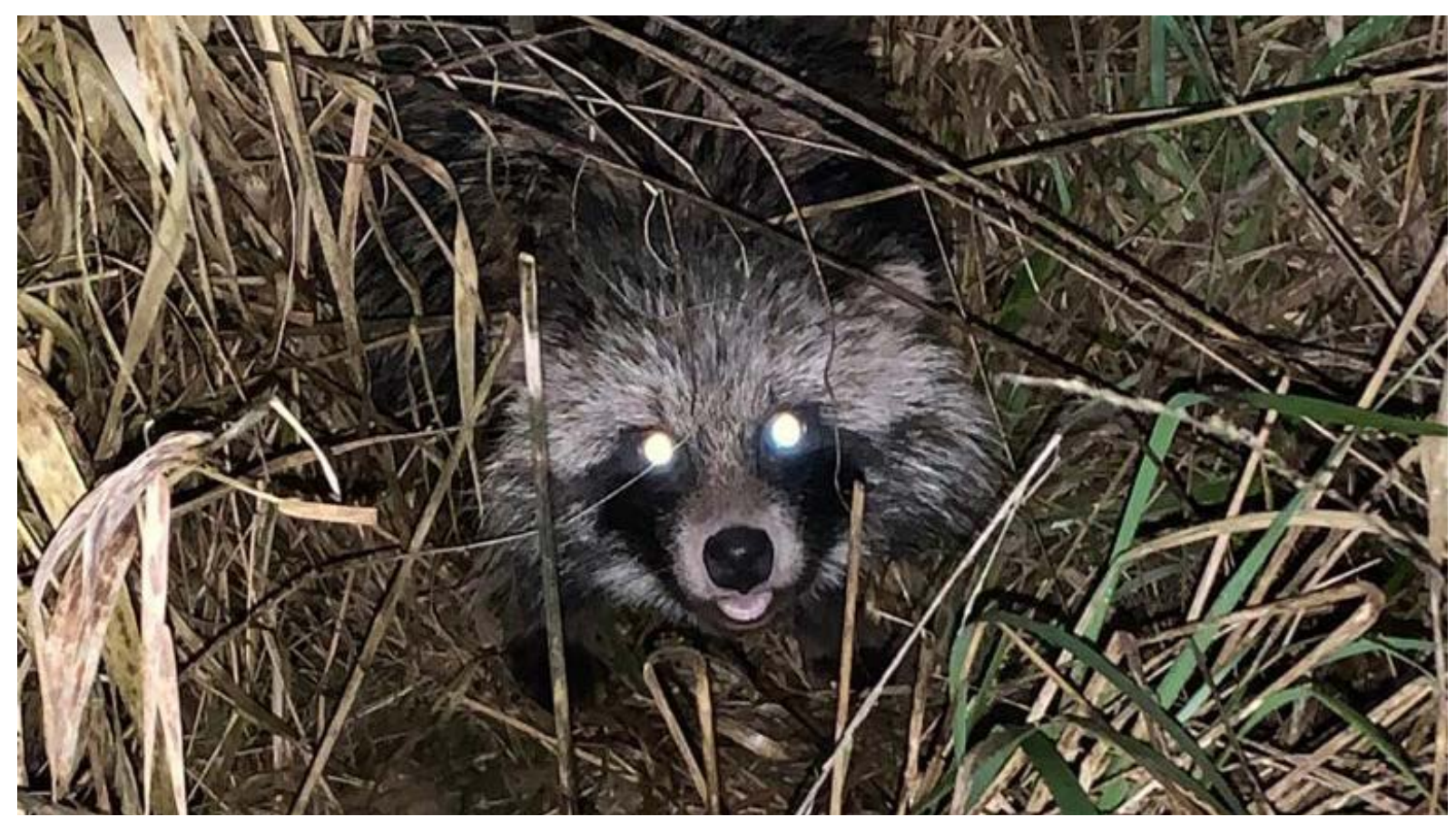

Fig. 1 - The first confirmed record of the raccoon dog Nyctereutes procyonoides in Luxembourg; (C) Danielle Hipp.

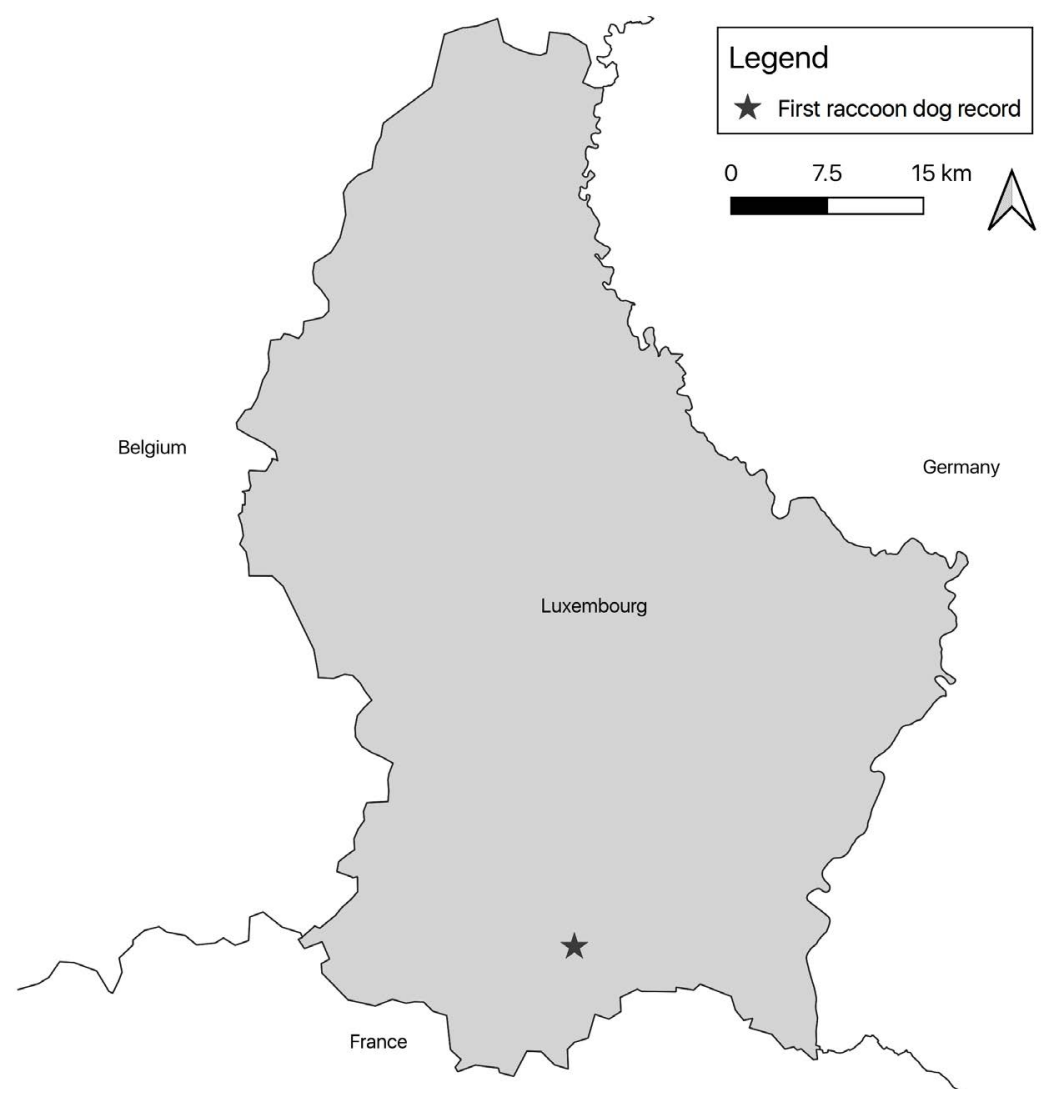

Fig. 2 - Location of the first confirmed record of the raccoon dog Nyctereutes procyonoides in Luxembourg. 


\section{References}

1. KAUHAla K. (1999). Nyctereutes procyonoides (Gray, 1834). In: Mitchell-Jones A.J. et al. (eds) The Atlas of European Mammals: 320-321. Poyser Natural History, T. \& A.D. Poyser, London.

2. KAUHALA K. \& KOWALCZYK R. (2011). Invasion of the raccoon dog Nyctereutes procyonoides in Europe: history of colonization, features behind its success, and threats to native fauna. Current Zoology 57 (5): 584-598. https://doi.org/10.1093/czoolo/57.5.584

3. BARBU P. (1972). Beiträge zum Studium des Marderhundes, Nyctereutes procyonoides ussuriensis Matschie, 1907, aus dem Donaudelta. Säugetierkundliche Mitteilungen 20 (4): 375-405.

4. Duscher T. \& NOPP-MAYR U. (2017). Species distribution modeling for the invasive raccoon dog (Nyctereutes procyonoides) in Austria and first range predictions for alpine environments. Archives of Biological Sciences 69: 637-647. https://doi.org/10.2298/ABS161124009D

5. LiBois R. (2006). Les mammifères non volants de la région wallonne : tendances des populations. Dossier scientifique réalisé dans le cadre de l'élaboration du rapport analytique 2006 sur l'état de l'environnement wallon. Unité de Recherches zoogéographiques, Université de Liège, 127 p.

6. Duplić A., SlijepČEvić V., Popović N. \& JedRišKo P. (2016). First record of the raccoon dog (Nyctereutes procyonoides) in the Croatian parts of Dinarides. In: JELASKA S.D. (ed.) Book of abstracts of the second Croatian symposium on invasive species, 21-22 November 2016. Croatian Ecological Society, Zagreb, Croatia.

7. LÉGER F. \& RUETTE S. (2005). Le chien viverrin en France. Faune sauvage 269: 4-13.

8. LÉGER F. \& RUETTE S. (2014). Raton laveur et chien viverrin : le point sur leur répartition en France. Faune sauvage 302: 9-16.

9. ĆIROVIĆ D. (2006). First record of the raccoon dog (Nyctereutes procyonoides Gray, 1834) in the former Yugoslav Republic of Macedonia. European Journal of Wildlife Research 52 (2): 136-137. https://doi.org/10.1007/s10344-005-0106-Z

10. MuldeR J.L. (2013). The raccoon dog (Nyctereutes procyonoides) in the Netherlands: its present status and a risk assessment. Lutra 56 (1): 23-43.

11. Weber J.-M., Fresard D., CAPt S. \& Noel C. (2004). First records of raccoon dog, Nyctereutes procyonoides (Gray, 1834), in Switzerland. Revue suisse de Zoologie 111: 935-940. https://doi.org/10.5962/bhl.part.80278

12. Naderi M., Çoban E., Kusak J., Kemahli Aytekin M.C., Chynoweth M., AĞIRKaya I.K., GÜVEn N., ÇOBAN A. \& ŞEKERCIOĞLU C.H. (2020). The first record of raccoon dog (Nyctereutes procyonoides) in Turkey. Turkish Journal of Zoology 44: 209-213. https://doi.org/10.3906/zoo-1910-29

13. Schley L., Schanck C., Schaul M. \& Sinner C. (2001). Neubürger und Heimkehrer unter den Wildtieren Luxemburgs. Beiträge zur Jagd- und Wildforschung 26: 141-154.

14. SCHLEY L. \& REDING R. (2012). Technischer Bericht der Naturverwaltung betreffend Wildtiermanagement und Jagd, vol. 2. Naturverwaltung, Luxemburg, 68 p.

15. SChley L., Reding R. \& CELlina S. (2014). Technischer Bericht der Naturverwaltung betreffend Wildtiermanagement und Jagd, vol. 3. Naturverwaltung, Luxemburg, 72 p.

16. PIR J.B. \& SChley L. (2015). Développement des connaissances sur la répartition et l'écologie des mammifères au Luxembourg entre 1990 et 2015. Bulletin de la Société des Naturalistes luxembourgeois 116: 437-455.

17. AnONyMOus (2011). Loi du 25 mai 2011 relative à la chasse. Memorial A 111: 1727-1741. 
18. ANONYMous (2014). Regulation (EU) No 1143/2014 of the European Parliament and of the Council of 22 October 2014 on the prevention and management of the introduction and spread of invasive alien species. Official Journal of the European Union L 317: 35-55.

19. ANONYMOUS (2017). Commission implementing regulation (EU) 2017/1263 of 12 July 2017 updating the list of invasive alien species of Union concern established by implementing regulation (EU) 2016/1141 pursuant to regulation (EU) No. 1143/2014 of the European Parliament and of the Council. Official Journal of the European Union L 182: 37-39.

20. BAIWY E., SCHOCKERT V. \& BRANQUART E. (2013). Risk analysis of the raccoon dog Nyctereutes procyonoides - Risk analysis report of non-native organisms in Belgium. Cellule interdépartementale sur les Espèces invasives (CiEi), DGO3, SPW/Éditions, 37 p.

21. MULDER J.L. (2012). A review of the ecology of the raccoon dog (Nyctereutes procyonoides) in Europe. Lutra 55 (2): 101-127.

22. SChLEY L. \& JACOBS M. (2020). Technischer Bericht der Naturverwaltung betreffend Wildtiermanagement und Jagd, vol. 8. Naturverwaltung, Luxemburg, 52 p.

23. Helle E. \& Kauhala K. (1991). Distribution history and present status of the raccoon dog in Finland. Holarctic Ecology 14: 278-286. https://doi.org/10.1111/j.1600-0587.1991.tb00662.x

24. Helle E. \& Kauhala K. (1995). Reproduction of the raccoon dog in Finland. Journal of Mammalogy 76: 1036-1046. https://doi.org/10.2307/1382597

25. SChley L., JaCobs M., Collet S., KRistiansen A. \& HeRR J. (2021). First wolves in Luxembourg since 1893, originating from the Alpine and Central European populations. Mammalia, published online 5 January 2021. https://doi.org/10.1515/mammalia-2020-0119

26. HePtNeR V.G. \& NAUMOV N.P. (1998). Mammals of the Soviet Union II, Part 1a. Science Publishers, Inc., New Hampshire.

27. KowALCZYKR.,ZALEWSKIA.,JĘDRZEJEWSKAB.,ANSORGEH.\&BUNEVICHA.N.(2009).Reproduction and mortality of invasive raccoon dogs (Nyctereutes procyonoides) in the Białowieża Primeval Forest (eastern Poland). Annales Zoologici Fennici 46: 291-301. https://doi.org/10.5735/086.046.0406

Received: 14 February 2021

Accepted: 30 March 2021

Published on: 12 April 2021

Branch editor: Johan Michaux 